\title{
DEVELOPMENT OF SOFTWARE TO DETERMINE PRESSURES IN MULTICELULARSILOS WITH CONCENTRIC AND ECCENTRIC DISCHARGE
}

\author{
Hellen Pinto Ferreira Deckers \\ Federal University of the Valleys Jequitinhonha and Mucuri (UFVJM), Campus Unaí, Institute of Agrarian Sciences \\ (ICA), ZIP Code 38610-298, Unaí, MG, Brazil \\ Corresponding author: hellen.deckers@ufvjm.edu.br
}

\section{Francisco Carlos Gomes}

Federal University of Lavras (UFLA), Engineering Dept., Campus, P. O. Box 3037, ZIP Code 37200-000, Lavras, MG, Brazil

\section{Larissa Pereira Barbosa Silva}

Federal University of the Valleys Jequitinhonha and Mucuri (UFVJM), Campus Unaí, Institute of Agrarian Sciences (ICA), ZIP Code 38610-298, Unaí, MG, Brazil

\section{Marília Gabriela Brandão Gonçalves}

Federal University of the Valleys Jequitinhonha and Mucuri (UFVJM), Campus Unaí, Institute of Agrarian Sciences (ICA), ZIP Code 38.610-298, Unaí, MG, Brazil

\section{Marcelo Bastos Cordeiro}

Federal University of the Valleys Jequitinhonha and Mucuri (UFVJM), Campus Unaí, Institute of Agrarian Sciences (ICA), ZIP Code 38610-298, Unaí, MG, Brazil

\begin{abstract}
A computer program for determining the pressures, horizontal and friction, in prismatic slender silos, with square section, eccentric hopper and mass flow, international codes taken as basis were: AS 3774 (1996), DIN 1055-6 (2005) and BS EN 1991-4 (2006) and the theories proposed by Safarian (1969) and Walker (1966). The development application was made possible by the development of a computational algorithm in programming "Borland Delphi". The program was carried out for five silos projects with truncated pyramid form hopper considering the following eccentricities: $25 \%, 30 \%, 35 \%$ and $43 \%$, as well as a concentric model for comparison. The computer program allowed SILOEXCENTRIC easily and quickly be applied to slender prismatic geometry of silos with concentric and eccentric hoppers. The results demonstrated the efficiency of the computer program for the proposed objectives So SILOEXCENTRIC results in pressures that are stored in files in "Notepad" format that may be accessed are generated. Besides files, various data are presented in graphical form, facilitating the assessment of horizontal pressures and friction, which proved adequate to international standards, considering the limit states.
\end{abstract}

Index terms: Eccentric discharge, prismatic slender silos, horizontal pressure and friction.

Received: June 14, 2019 - Accepted: January, 10, 2020

\section{INTRODUCTION}

One of the sectors that has grown in recent years is the production of processed foods, both for human consumption and for the animal, as the rations. With the development of projects, vertical plants require multicellular structures, for storage of raw material, suitable for the production, considering the physical properties of the product.
According to Brown and Nielsen (1998), the design and behavior of rectangular and square silos are very different from cylindrical silos. Quantities such as pressures and displacements, their interaction and importance in the behavior prismatic silos, still poorly understood. According to Calil Júnior et al. (1997), prismatic wall shaped silos are more economical because of the rigidity of the plates. In the pioneering study by Ravenet (1992), were executed with two 
conformations of wall: trapezoidal and zigzag, which are still used today in industries.

The eccentric discharge allows the optimization of the use of conveyors and facilitates the access of trucks and trains in the unloading of the products. The disadvantage is that, in this situation, non-uniform pressures arise, along the perimeter of the silo, considered the major cause of collapses (Molenda et al., 2001). Despite these advantages, vertical prismatic silos are still little used, in part, due to the simple ignorance of its benefits. And in part, because of the lack of technical knowledge required for its design and construction (Lopes Neto et al., 2008).

This work aimed to develop a computational program to determine the, horizontal pressure and friction, in prismatic slender silos, of square section, with eccentric hopper, with eccentric hopper and mass flow, on the basis of international standards: AS 3774 (1996), DIN 1055-6 (2005) e BS EN 1991-4 (2006) and the theories proposed by Safarian (1969) and Walker (1966).

\section{MATERIAL AND METHODS}

The development of the program, was carried out for five prismatic silos with trunk-pyramidal hopper, considering the following eccentricities: $25 \%, 30 \%, 35 \%$ and $43 \%$ a concentric model for comparison. The software interface is simple for interaction between user supplied data, such as stored product properties, silo and hopper geometric properties, and the results obtained from mass flow pressures, being structured in three steps:

\section{Step 1: Determination of Silo Geometry:}

Firstly, it is important to consider the assays for product characterization of the products to be stored, whenever possible, recommended by BS EN 1991-4 (2006), use the mean values, tables by the standards, to determine silo geometry. To evaluate the pressures, due to the stored product, the values obtained from the physical properties obtained by Lopes Neto and Nascimento (2013) were used as an example. In addition to the different geometries, such as computer program input data for mass flow, the products were classified as granular, powdery and cohesive powdery.

For the dimensional calculation of the five prismatic silos a capacity of 100 tons of product was adopted. The adopted cell capacity deals with the boundary between the stock rating class for DIN 1055-6 and BS EN 1991-4, and thus the behavior of pressures in Classes 1 or 2 and 3 can be observed.

For the calculation of pressures, a hopper slope determined by Equation 1 suggested by Mclean (1986) was adopted to ensure mass flow in the five hopper silos.

$\hat{a}_{\text {crit }}=0,5 \cdot\left[180-\cos ^{-1}\left(\frac{\left(1-\operatorname{sen} \phi_{e}\right)}{2 \cdot \operatorname{sen} \phi_{e}}\right)-\left(\phi_{w}+\operatorname{sen}^{-1} \frac{\operatorname{sen} \phi_{w}}{\operatorname{sen} \phi_{e}}\right)\right]$

where: $\beta_{\text {crit }}$ is the critical angle of the hopper with the vertical $\left({ }^{\circ}\right), \phi_{e}$ is the effective internal friction angle $\left(^{\circ}\right)$ and $\phi_{\mathrm{w}}$ is the product's friction angle with the wall $\left({ }^{\circ}\right)$.

The critical angles calculated between the hopper wall and the vertical $\left(\beta_{\text {crit }}\right)$ for each product were: $\beta_{\text {crit }}($ corn $)=34^{\circ}, \beta$ crit (crushed corn $)=27^{\circ}$ and $\beta_{\text {crit }}$ (soybean meal $)=25^{\circ}$. Since these are square cells used in multicellular silos, the most unfavorable situation of $25^{\circ}$ was adopted. This choice meets all three products, given the larger slope of the hopper wall, which ensures mass flow.

For analysis purposes, five geometries were adopted: concentric hopper silo and eccentric hopper silos. For the concentric hopper silo, the calculation methodologies proposed by the analyzed standards were applied (Figure 1). The second geometry corresponds to an eccentric hopper silo, that is, they are hoppers with the $\mathrm{e}_{\mathrm{o}} / \mathrm{a}$ ratio (discharge mouth eccentricity / silo body wall width) of $25 \%, 30 \%, 35 \%$ and $43 \%$ eccentricity (Figure 2). The choice of eccentric geometry allows the study of Safarian (1969), called the imaginary silo, adopted by ACI 313 (1977).

The effective height of the silo $(\mathrm{H})$ was determined considering AS 3774, where it is prescribed that for prismatic silos the equivalent height is the sum of half of the resting height $\left(h_{t p}\right)$, the silo body height $\left(h_{c}\right)$ and the hopper height $\left(h_{t}\right)$. The five studied silos were classified 
as slender, according to the three standards analyzed, according to the $\mathrm{H} /$ a ratio.

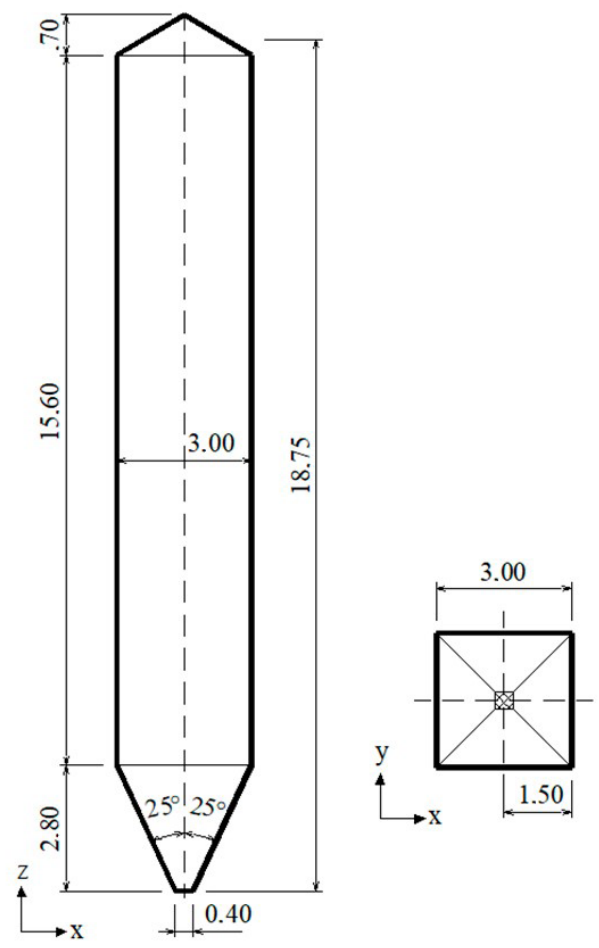

Figure 1: Schematic drawing and dimensions, in meters, of the silo with a concentric hopper.

\section{Step 2: Calculation of pressures:}

Horizontal and friction pressures were calculated in prismatic slender silos, square section, with eccentric and concentric discharge according to the formulation of the main standards (BS EN 1991-4, DIN 1055-6 and AS 3774) and Safarian theories (1969) and Walker (1966) making it possible to compare them, for static and dynamic pressures, in the silo body and in the hopper.

\section{Step 3: Development of the computer pro- gram:}

The program developed, called SILOEXCENTRIC, to systematize the procedures in slender silos, square section, eccentric hopper (25\%, 30\%, 35\% and 43\%) and concentric silos. For calculating the concentric and eccentric loading and unloading pressures, the silo and hopper body according to the flow chart shown in Figure 3.

The software was developed in Delphi XE 32Bits environment, called SILOEXCENTRIC. For the determination of the pressures due to the stored product, the formulations of the studied norms and theories of Safarian (1969) and Walker (1966) were used.

The program structure is based on a first screen with the input data of the physical properties of the stored products (Figure 4). There is a spreadsheet at the bottom of the screen, being a data entry module, to enter the

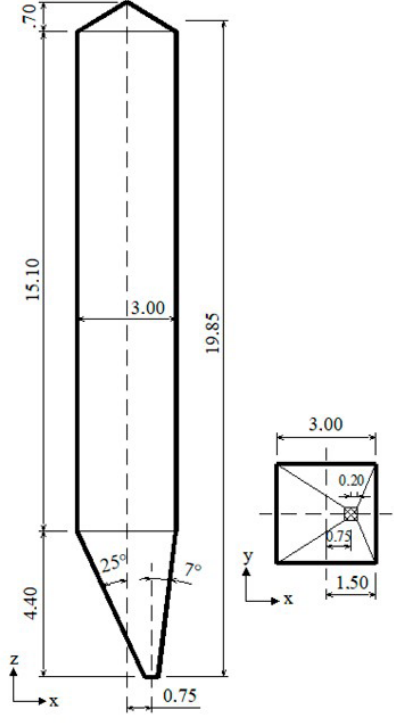

(a)

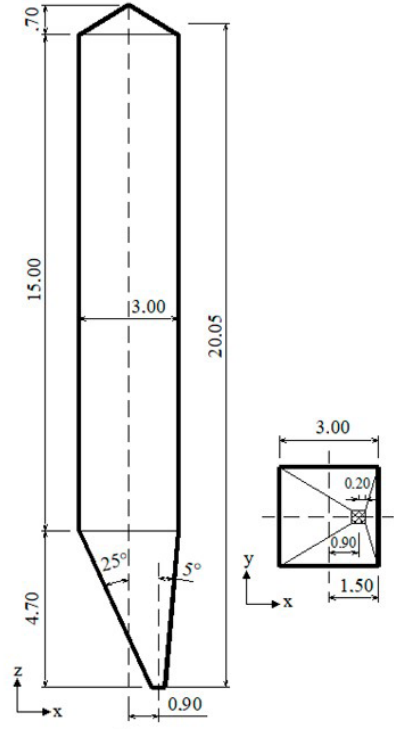

(b)

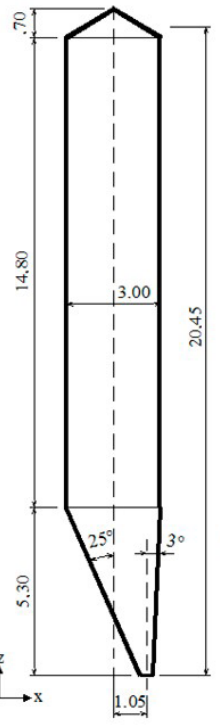

(c)

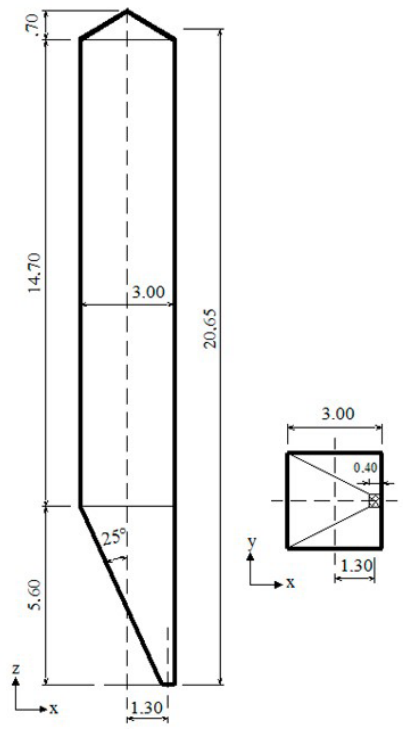

(d)

Figure 2: Schematic drawing and dimensions in meters of eccentric hopper silos: (a) 25\% eccentricity, (b) 30\% eccentricity, (c) 35\% eccentricity and (d) $43 \%$ eccentricity. 


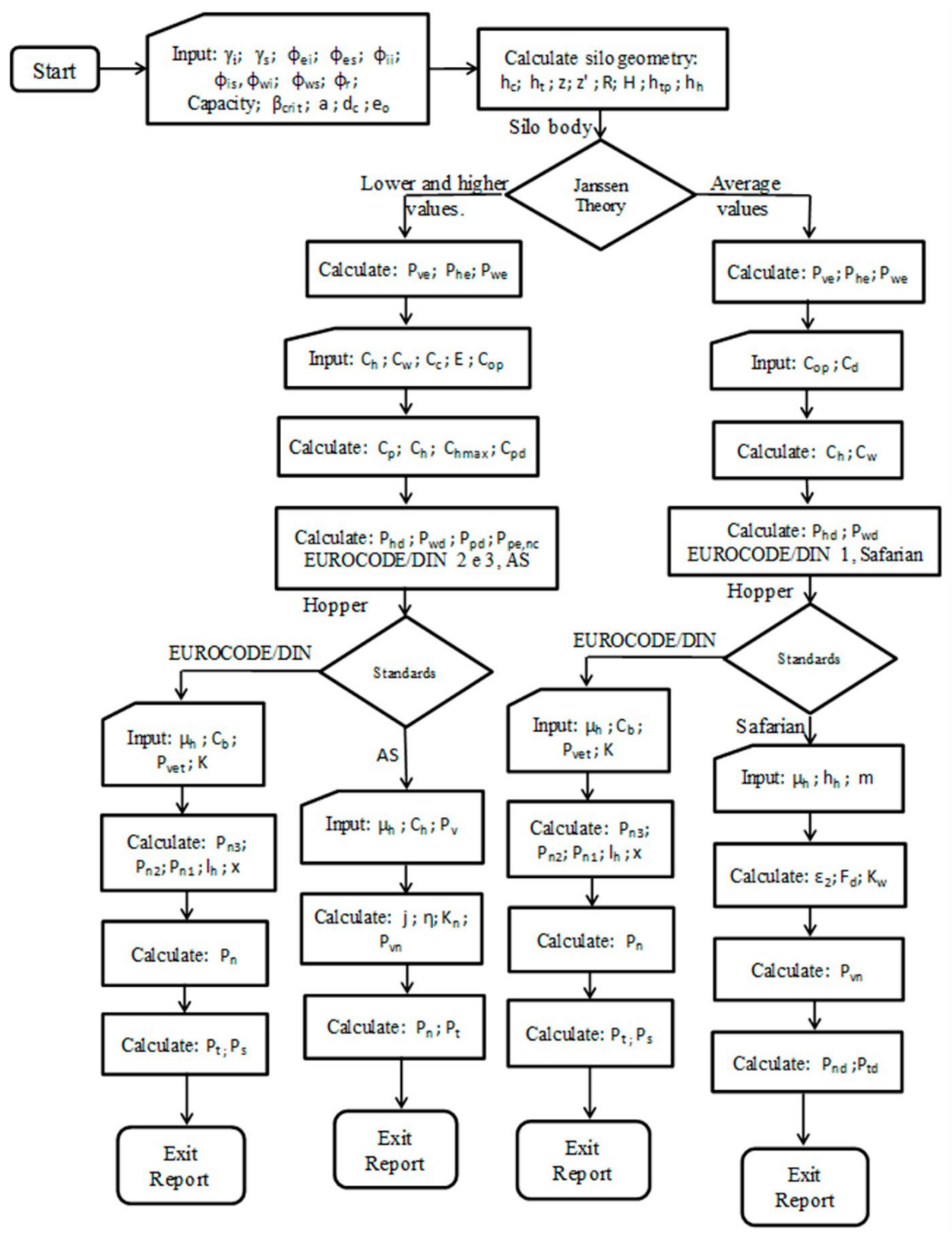

Figure 3: Simplified flowchart of the computational program.

Note: $\gamma_{\mathrm{i}}=$ specific weight of under stored product, $\gamma_{\mathrm{s}}=$ specific weight of the upper stored product, $\phi_{\mathrm{ii}}=$ lower internal friction angle, $\phi_{\mathrm{is}}=$ upper internal friction angle, $\phi_{\mathrm{ei}}=$ effective lower internal friction angle, $\phi_{\mathrm{es}}=$ effective upper internal friction angle, $\phi_{\mathrm{wi}}=$ friction angle with the bottom wall, $\phi_{\mathrm{ws}}=$ friction angle with the bottom wall, $\mathrm{a}=$ silo cell wall width, $\mathrm{H}=$ effective silo height (from outlet to equivalent surface), $h_{t}=$ hopper height, $h_{h}=$ hopper height (from its axis to the transition), $h_{t p}=$ resting height of stored product, $\mathrm{e}_{\mathrm{o}}=$ discharge mouth eccentricity, $\mathrm{b}_{\mathrm{f}}=$ output mouth width, $\beta_{\text {crit }}=$ critical angle of the hopper with the vertical, $\beta=$ hopper angle with the vertical, $h_{c}=$ silo body height, $P_{v e}=$ static vertical pressure, $P_{\text {he }}=$ static horizontal pressure, $P_{w e}=$ static vertical friction pressure, $\mu=$ coefficient of friction of the product with the wall, $\gamma=$ specific weight of stored product, $K=$ relationship between horizontal and vertical pressure, $\mathrm{P}_{\mathrm{pe}}=$ static additional pressure, $\mathrm{C}_{\mathrm{pe}}=$ static additional pressure coefficient, $\mathrm{E}=$ relationship between flow channel eccentricity $(\mathrm{e})$ and inscribed diameter $\left(\mathrm{d}_{\mathrm{c}}\right), \mathrm{C}_{\mathrm{op}}=$ coefficient of stored product, $\mathrm{P}_{\text {penc }}=$ static additional pressure for non-circular silos, $P_{h d}=$ dynamic horizontal pressure, $P_{w d}=$ dynamic vertical friction pressure, $\mathrm{C}_{\mathrm{h}}=$ overpressure coefficient for horizontal pressures, $\mathrm{C}_{w}=$ overpressure coefficient for friction pressure, $\mathrm{C}_{c}=$ product geometry coefficient, $\mathrm{P}_{\mathrm{pd}}=$ dynamic additional pressure, $\mathrm{C}_{\mathrm{pd}}=$ dynamic additional pressure coefficient, $\mathrm{P}_{\mathrm{pd}, \mathrm{c}}=$ dynamic additional pressure for non-circular silos, $\mathrm{P}_{\mathrm{n} 1}=$ hopper pressure due to the vertical pressure caused by the storage of the product in the transition region, $P_{n 2}=$ hopper pressure due to the vertical pressure caused by storage of the product at the hopper output, $P_{n 3}=$ hopper pressure due to weight of product in hopper, $C_{b}=$ hopper overpressure coefficient, $C_{h}=$ overpressure coefficient for horizontal pressures, $\mathrm{P}_{\mathrm{t}}=$ vertical friction pressure per hopper perimeter unit, $\mathrm{P}_{\mathrm{s}}=$ transition pressure applied to mass flow silos. 
physical properties of various products with their characteristics. As an example, the physical properties of the products can be observed: corn, crushed corn and soybean meal, because hey are products with differentiated properties. Since the corn is classified as a granular product, corn crushed is a cohesive powdery product, while soybean meal is a powdery product.

Figure 5 shows the screen with cell capacity input data and silo geometric characteristics for each eccentric or concentric hopper. Figure 6 has the input data of the coefficients for the silo body and the hopper for the calculation of the dynamic pressures, according to the studied norms and Safarian's theory (1969).

\section{RESULTS AND DISCUSSION}

The SILOEXCENTRIC presents on the screen titled "Calculations of Pressure", the calculation parameters, being the type of stored product and the eccentricities, for concentric and eccentric hopper, as shown in Figure 7. For the different calculation procedures, with their codes. from 1 to 6. The estimation of the flow pattern was performed by the equation proposed by Mclean (1986).

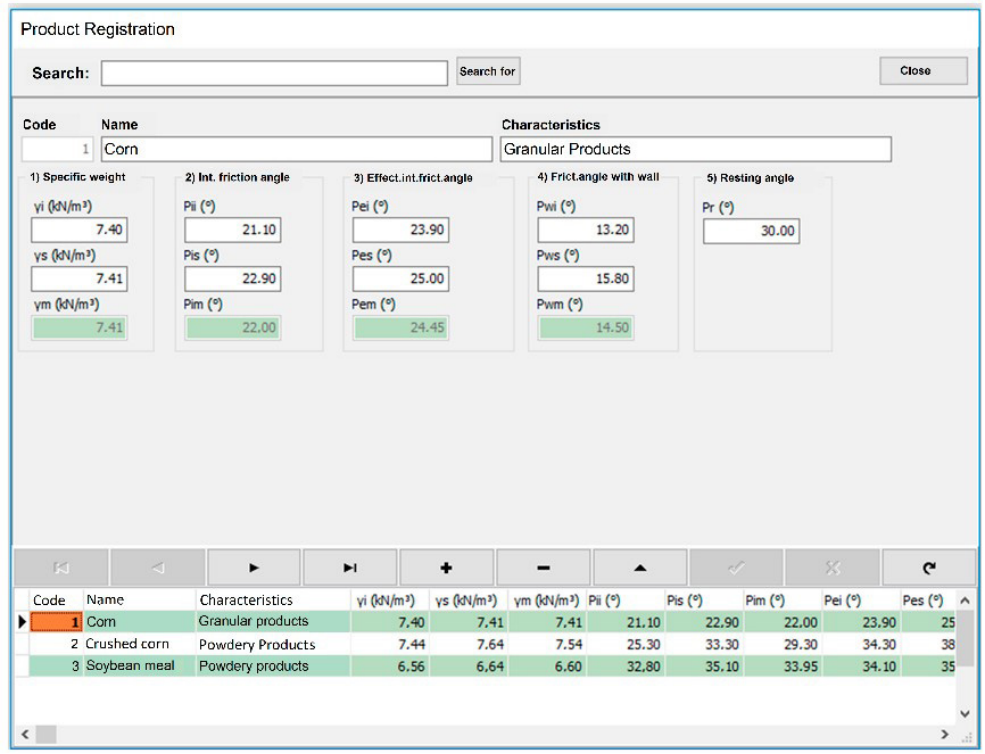

Figure 4: Registration screen of the physical properties of stored products, for example: corn product.

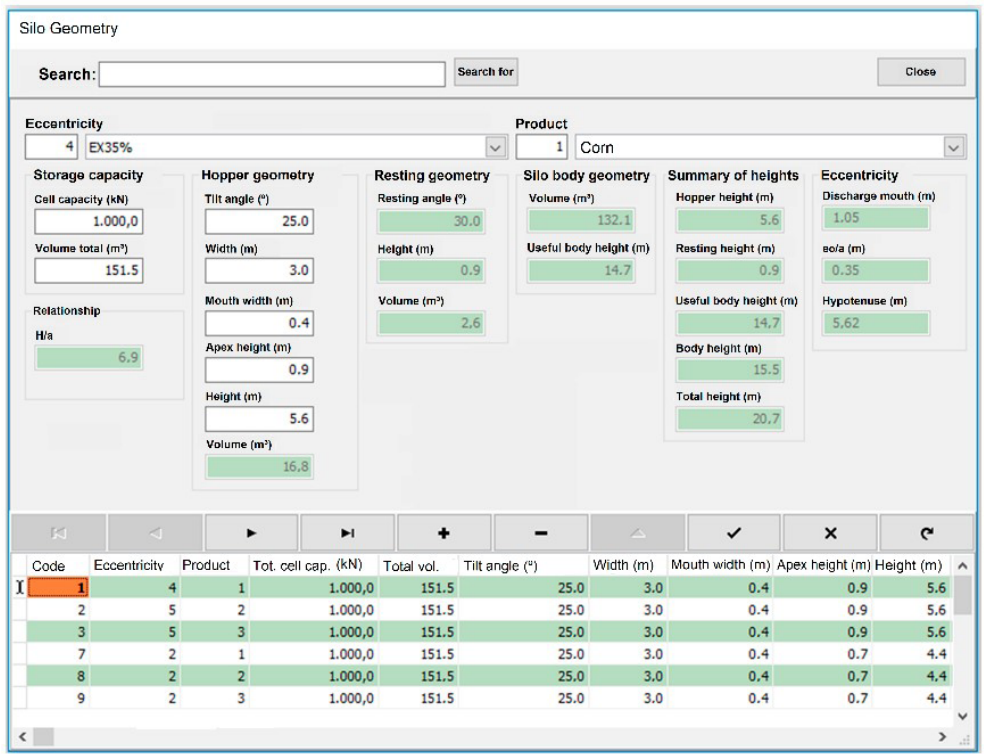

Figure 5: Capacity screen and geometric characteristics of the silo, for example: $35 \%$ eccentricity and corn product. 


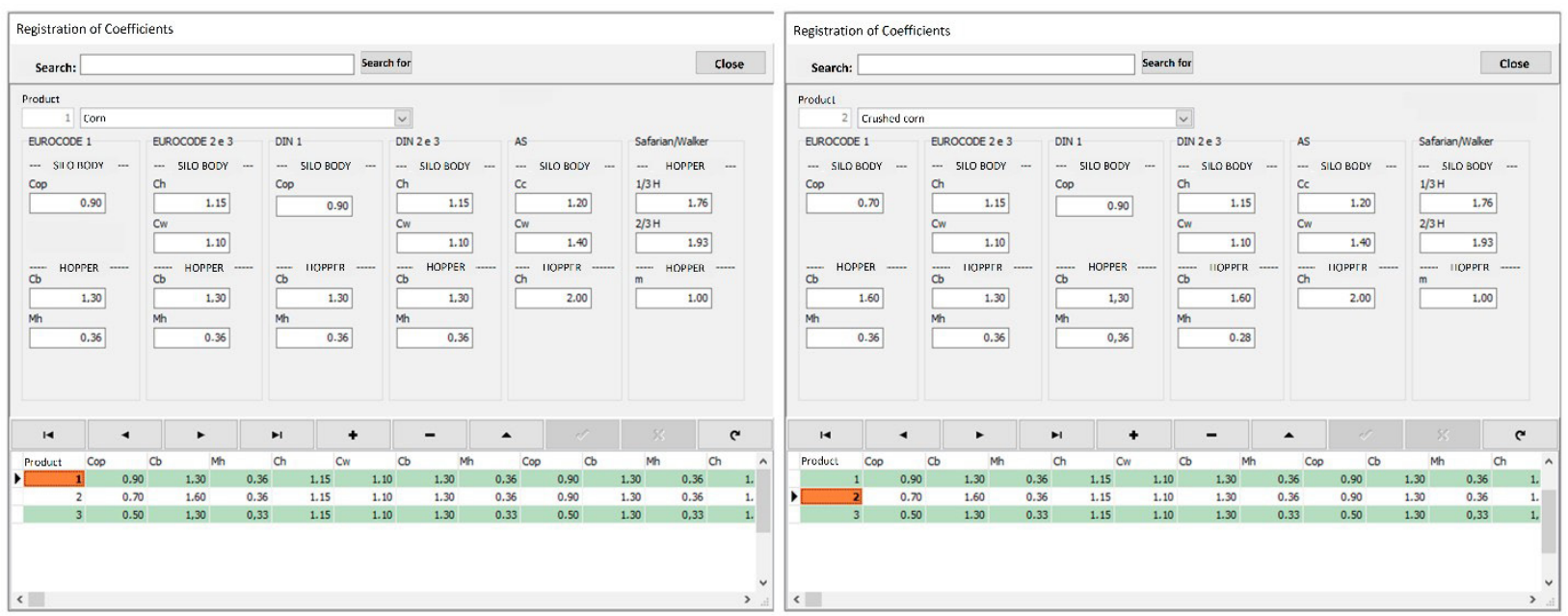

Figure 6: Coefficient registration screen for the silo and hopper body, for example: corn product and crushed corn.
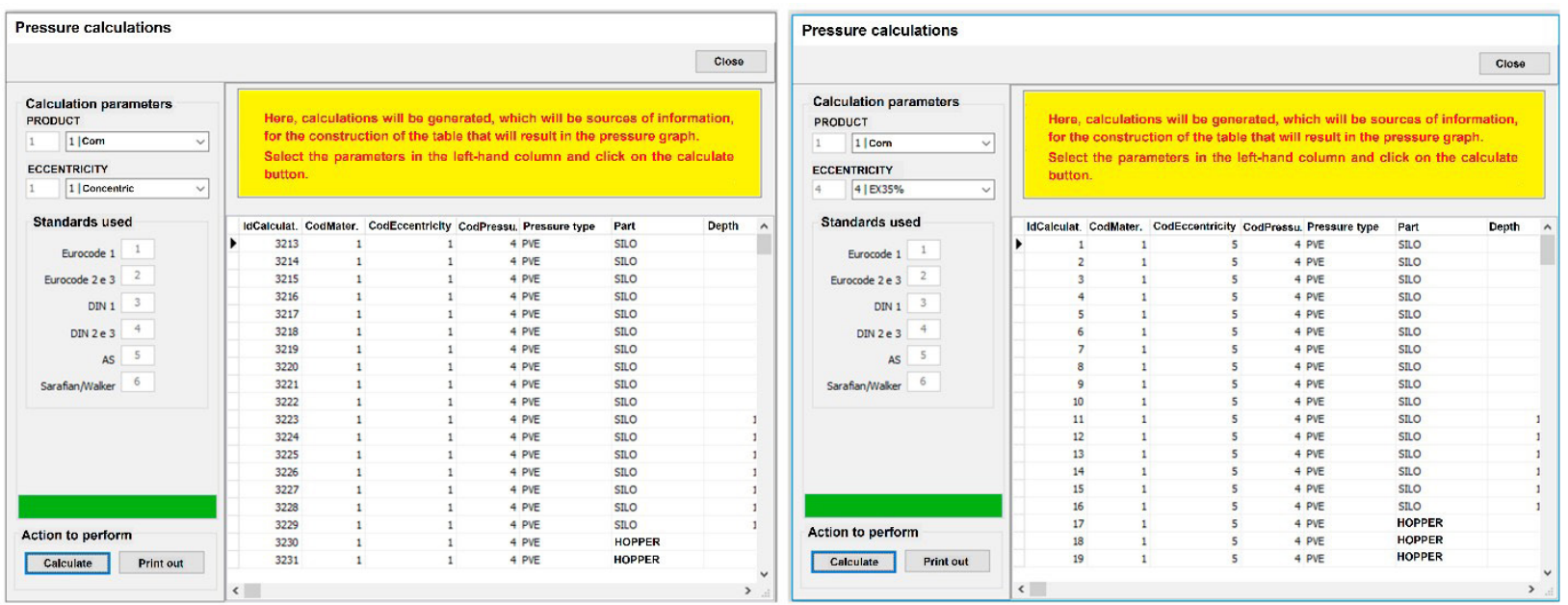

Figure 7: Pressure calculation screen, selecting stored product option and hopper type, for example: corn product and eccentricity: concentric and 35\%.

The results are output by means of a notepad, showing the results of the pressures: static vertical pressure, static horizontal pressure, dynamic horizontal pressure and dynamic friction pressure (Figure 8). In addition to plotting the graphs as a function of the height of the silo and hopper body, on the "Graphs Visualization" screen having as parameters the product, the eccentricity and the pressure.

\section{a) Static horizontal pressure in the silo}

With the static horizontal pressures calculated at the bottom of the silo body, with eccentric output, mean values of $21.11 \mathrm{kN} . \mathrm{m}^{-2}$ for the corn, $13.33 \mathrm{kN} . \mathrm{m}^{-2}$ for the crushed corn and $11.00 \mathrm{kN} . \mathrm{m}^{-2}$ for the soybean meal. These values were on average $1 \%$ lower than those observed in concentric output silos whose average values are $21.39 \mathrm{kN} . \mathrm{m}^{-2}$ for corn, 13.53 $\mathrm{kN} . \mathrm{m}^{-2}$ for corn crushed and $11.13 \mathrm{kN} . \mathrm{m}^{-2}$ for soybean meal, by standards and Safarian's theory (1969).

For the static horizontal pressures calculated at the transition of the eccentric hoppers, average values are $45.32 \mathrm{kN} . \mathrm{m}^{-2}$ for corn, $39.36 \mathrm{kN} . \mathrm{m}^{-2}$ for crushed corn and $31.56 \mathrm{kN} . \mathrm{m}^{-2}$ for soybean meal. These values were on average $12 \%$ higher than the concentric hopper with average values of $40.02 \mathrm{kN} . \mathrm{m}^{-2}$ for corn, $34.57 \mathrm{kN} . \mathrm{m}^{-2}$ for crushed corn and $27.71 \mathrm{kN} . \mathrm{m}^{-2}$ for soybean meal, by EUROCODE and DIN standards.

Safarian's theory is that it has the lowest pressure values on average for all products, 


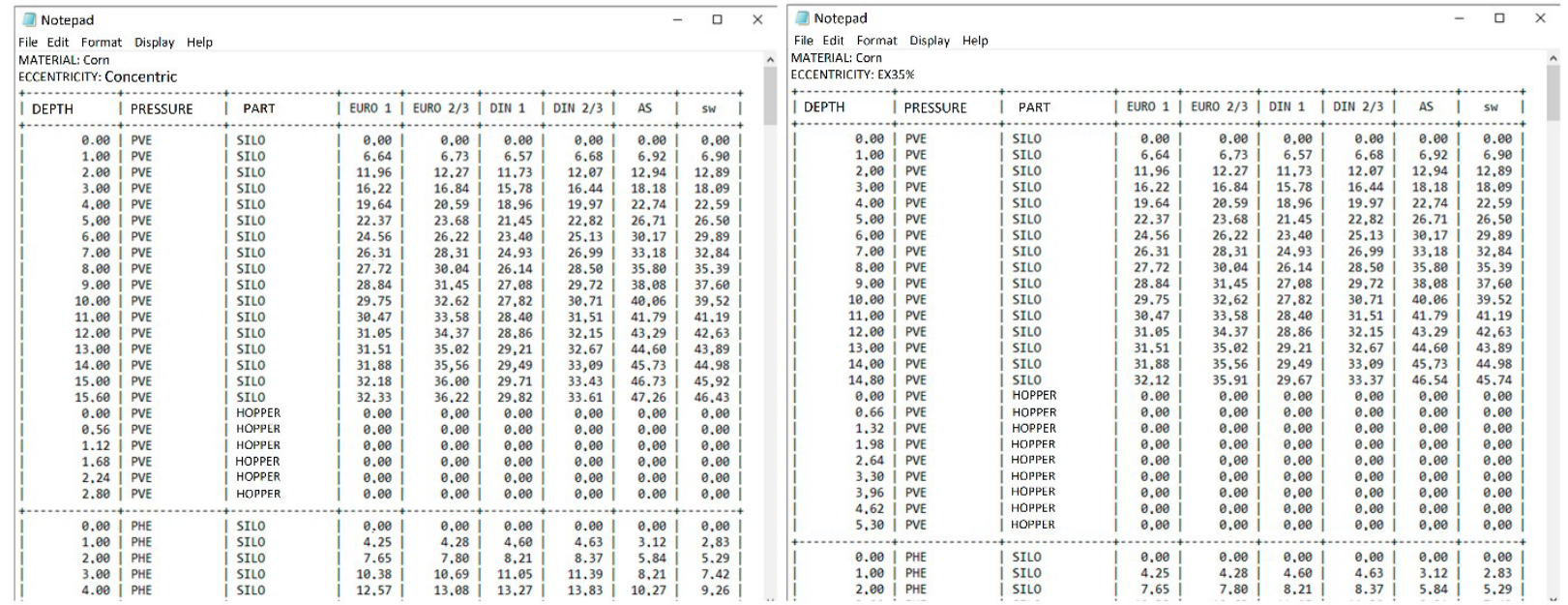

Figure 8: Pressure calculations report screen, by standards, Safarian and Walker theories, for example: corn product and eccentricity: concentric and 35\%.

followed by AS 3774 and EUROCODE / DIN standards, Class 1, which is lower than the average pressure of EUROCODE / DIN, Class 2 and 3 , located at the bottom of the silo body.

Madrona and Calil Júnior (2009), in the calculation for concentrichopper cylindrical silos, obtained static horizontal pressure for soybean higher than the static horizontal pressure with soybean meal, both in the body and in the silo hopper. At transition, the pressures given by the standards (EUROCODE, DIN and AS) average $28 \mathrm{kN} . \mathrm{m}^{-2}$ for crushed corn and $32 \mathrm{kN} . \mathrm{m}^{-2}$ for soybean.

Using Walker's theory (1966), eccentric hoppers showed, on average, static horizontal pressure values equal to $71.08 \mathrm{kN} . \mathrm{m}^{-2}$ for corn, $58.27 \mathrm{kN} . \mathrm{m}^{-2}$ for crushed corn, and $50.14 \mathrm{kN} . \mathrm{m}^{-2}$ for soybean meal. These values were on average $5 \%$ lower in relation to the concentric hopper with average values of $74.57 \mathrm{kN} . \mathrm{m}^{-2}$ for corn, 61.14 $\mathrm{kN} . \mathrm{m}^{-2}$ for crushed corn and $52.60 \mathrm{kN} \cdot \mathrm{m}^{-2}$ for soybean meal. Among the different eccentricities for the same product no difference was found in the static horizontal pressure.

When calculating static horizontal pressures in the hopper, higher values were observed when Walker's theory (1966) was adopted, as it adopted the depth based on the equivalent surface of the silo. As noted by Gaylord Junior and Gaylord (1984), Walker's theory (1966) overestimates the initial hopper pressures. Palma (2008) obtained, using Walker's theory
(1966), values around 50\% higher than Jenike's theory, for horizontal pressures in cylindrical silos, steel, with conical hopper for millet and soy products.

Figures 9 to 13 show the static horizontal pressure curves according to the norms and theories for the three products analyzed.

\section{b) Dynamic horizontal pressure in the silo}

In the dynamic horizontal pressures, calculated at the bottom of the silo body, with eccentric output, average values of $45.20 \mathrm{kN} . \mathrm{m}^{-}$ 2 for corn, $26.50 \mathrm{kN} . \mathrm{m}^{-2}$ for crushed corn and 20.93 kN.m ${ }^{-2}$ for soybean meal. Comparing with the same concentric output pressures, average values are $39.70 \mathrm{kN} \cdot \mathrm{m}^{-2}$ for corn, $23.24 \mathrm{kN} . \mathrm{m}^{-2}$ for crushed corn, and $18.34 \mathrm{kN} . \mathrm{m}^{-2}$ for soybean meal, by standards, and Safarian theory, which represents the $12 \%$ difference between the values.

For the dynamic horizontal pressures, calculated at the transition of the eccentric and concentric hoppers, average values equal to $77.81 \mathrm{kN} . \mathrm{m}^{-2}$ are observed for corn. For eccentric hoppers, the average values were $58.53 \mathrm{kN} . \mathrm{m}^{-2}$ for crushed corn and $46.88 \mathrm{kN} \cdot \mathrm{m}^{-2}$ for soybean meal. These values were on average $5 \%$ higher than the concentric hopper with average values equal to $55.45 \mathrm{kN} \cdot \mathrm{m}^{-2}$ for crushed corn and 44.46 $\mathrm{kN} \cdot \mathrm{m}^{-2}$ for soybean meal, by the norms, and theory of Walker. 


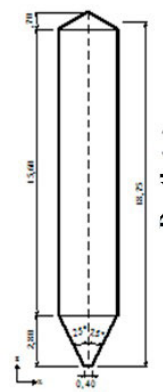

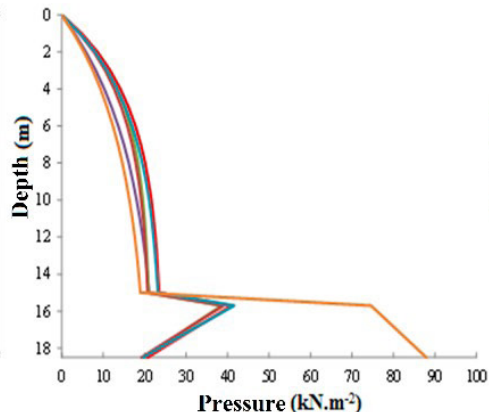

(a)

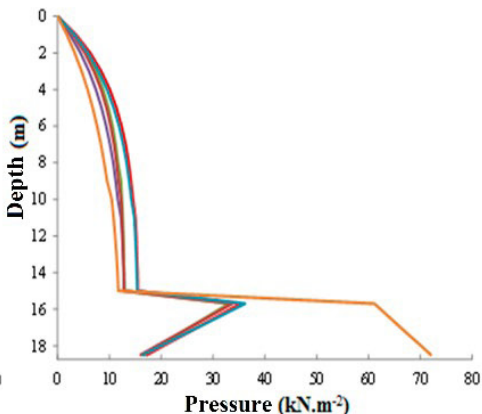

(b)

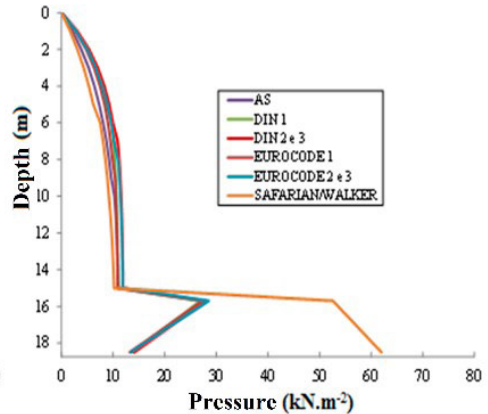

(c)

Figure 9: Static horizontal pressure (or loading) in the concentric hopper silo for: (a) corn, (b) crushed corn and (c) soybean meal.
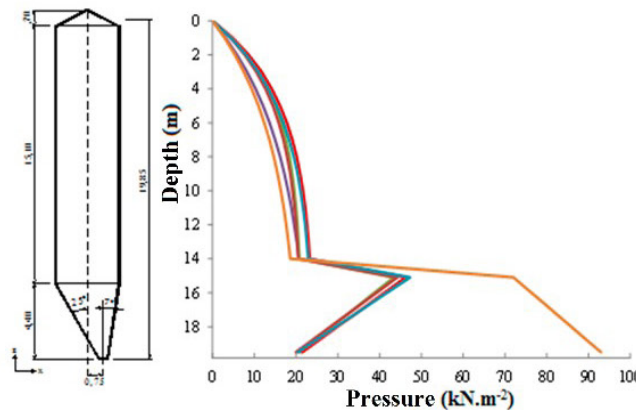

(a)

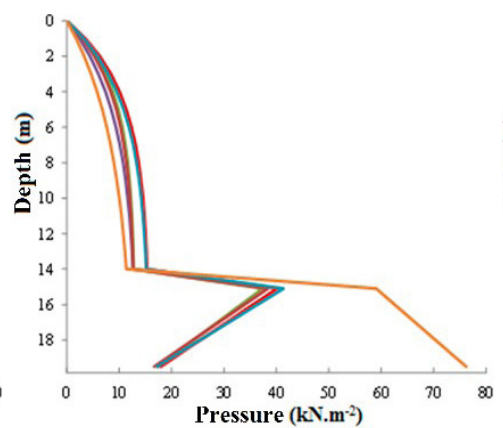

(b)

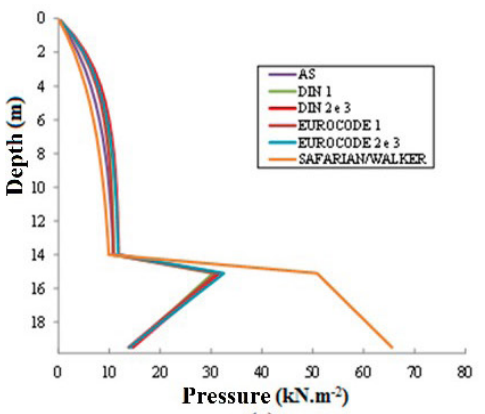

(c)

Figure 10: Static horizontal pressure (or loading) in the eccentric hopper silo $\left(\mathrm{e}_{\mathrm{o}} / \mathrm{a}=25 \%\right.$ ) for: (a) corn, (b) crushed corn and (c) soybean meal.
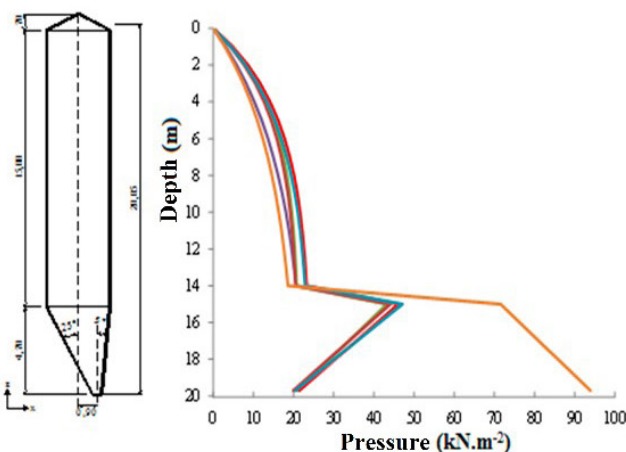

(a)

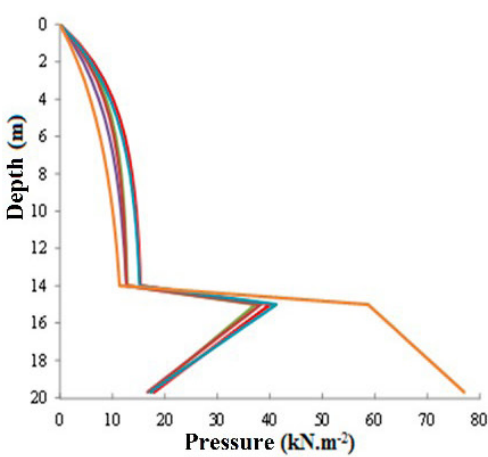

(b)

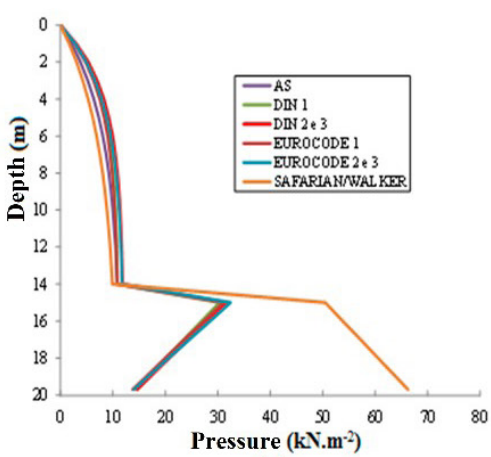

(c)

Figure 11: Static horizontal pressure (or loading) in the eccentric hopper silo $\left(\mathrm{e}_{\mathrm{o}} / \mathrm{a}=30 \%\right)$ for: (a) corn, (b) crushed corn and (c) soybean meal.

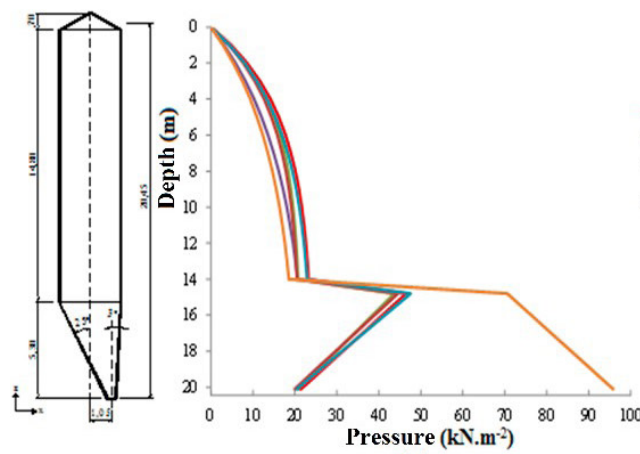

(a)

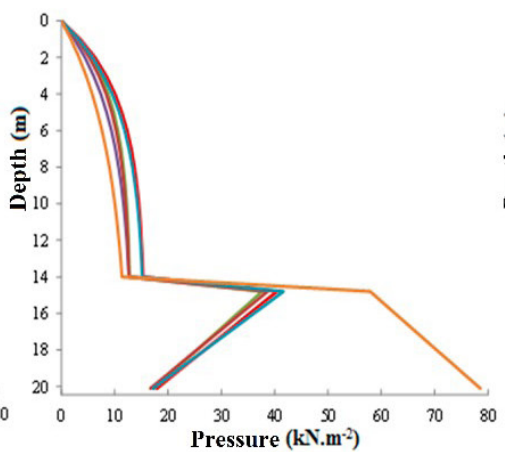

(b)

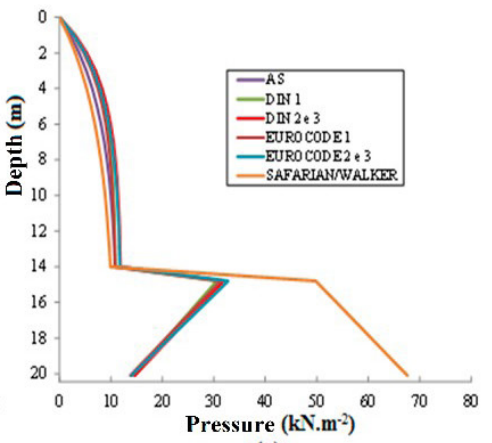

(c)

Figure 12: Static horizontal pressure (or loading) in the eccentric hopper silo $\left(\mathrm{e}_{\mathrm{o}} / \mathrm{a}=35 \%\right)$ for: (a) corb, (b) crushed corn and (c) soybean meal. 


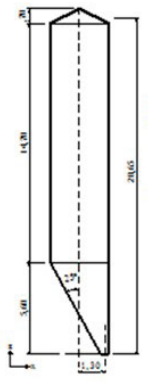

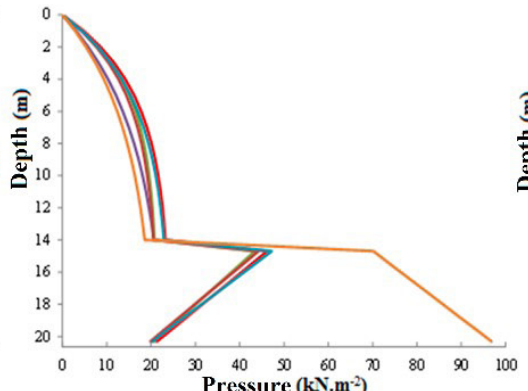

(a)

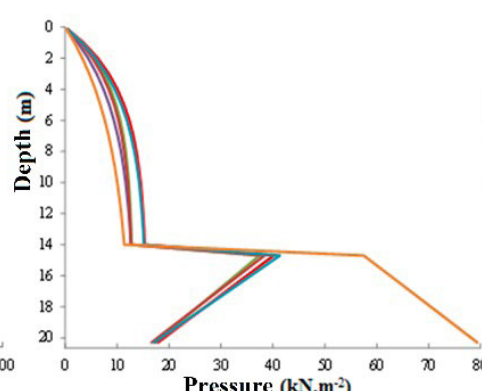

(b)

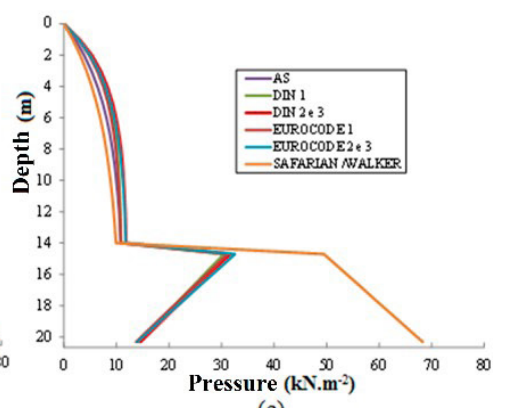

(c)

Figure 13: Horizontal static pressure (or loading) in the silo with eccentric hopper $\left(\mathrm{e}_{\mathrm{o}} / \mathrm{a}=43 \%\right)$ to: (a) corn, (b) crushed corn, and (c) soybean meal.

The EUROCODE and DIN (Class 2 and 3) standards have the lowest dynamic horizontal pressure at the bottom of the silo body for both products. This is because the lowest value of the overpressure coefficient is 1.15. Madrona and Calil Júnior (2009) presented the same result for eccentric hopper cylindrical silos. Whereas, for EUROCODE and DIN (Class 1) standards, they range from 1.98 to 2.73 for the overpressure coefficient, calculated according to product type and eccentricity. Palma (2008) calculated the pressure in concentric cylindrical silo having obtained values of 1.47 for soybean and 1.35 for millet, according to the EUROCODE and DIN standards. The overpressure coefficient calculated by Madrona and Calil Júnior (2009) for soybean storage in Class 1 eccentric hopper cylindrical silos ( $25 \%$ eccentricity) was less than 1 , with 1.15 , but in compensation, AS 3774 for soybeans and ground corn presented the highest pressures using an overpressure coefficient of 1.9.

Lopes Neto et al. (2008) found the values of overpressure coefficients of 1.5 (DIN), 1.55 (EUROCODE) and 1.72 (AS) and also K values of 0.53 (DIN), 0.49 (EUROCODE) and 0.35 (AS) when using prismatic silo of rectangular section, with walls in zigzag conformation with inclination of $70^{\circ}$ with the horizontal, using the pelletized soybean. These values of overpressure coefficients are lower than those calculated by SILOEXCENTRIC, and for $\mathrm{K}$ values, there was similarity with the values obtained for crushed corn and soybean meal.

Analyzing the overpressure coefficients, it is observed that for concentric silo, the overpressure coefficient is lower for all products compared to eccentric silo. The empirical formula for determining the overpressure coefficient takes into account the eccentricity and the higher the eccentricity the greater the coefficient.

Safarian's theory employs overpressure coefficients and considers that for mass flow the value of the overpressure coefficient must be increased by 10 to $25 \%$.

Figures 14 to 18 show the dynamic horizontal pressure curves according to the norms and theories for the three products analyzed.

\section{c) Dynamic vertical friction pressure in the silo}

For the three products, the coefficient of overpressure applied to static friction pressure in Class 1 silos (EUROCODE and DIN) ranges from 1.40 to 1.64 and for Class 2 and 3. This value is constant from 1.10. For Safarian the overpressure coefficient is $1.76(1 / 3 \mathrm{H})$ and $1.93(2 / 3 \mathrm{H})$. While the AS 3774 adopts 1.4 (planar flow) and 1.2 (funnel flow). In the study by Cheung (2007), in concentric slim cylindrical silo, for different products (soybean, corn and chicken feed) and wall types, average values were found from 1.07 to 1.076 for smooth wall, and from 1.098 to 1.134 for corrugated walls, these values being similar to those calculated by EUROCODE and DIN (Class 2 and 3), but lower than the others.

Madrona and Calil Júnior (2009) point out that the discharge overpressure coefficients of the standards were 1.54, (EUROCODE / DIN Class 1), 1.10 (EUROCODE / DIN Class 2 and 3) and 1.20 (AS) for cylindrical silo with $25 \%$ eccentricity for corn and soybean meal. Lopes Neto, Nascimento and Fank (2014) adopted the same value for AS 3774, 1.15 for EUROCODE and 1.10 for DIN for flat-bottomed concentric and eccentric discharge silo. 


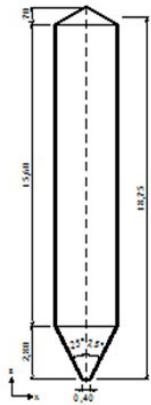

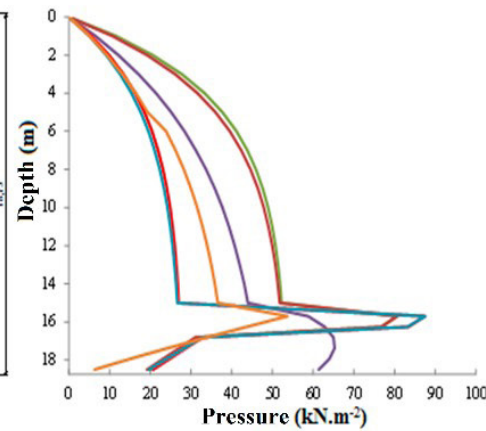

(a)

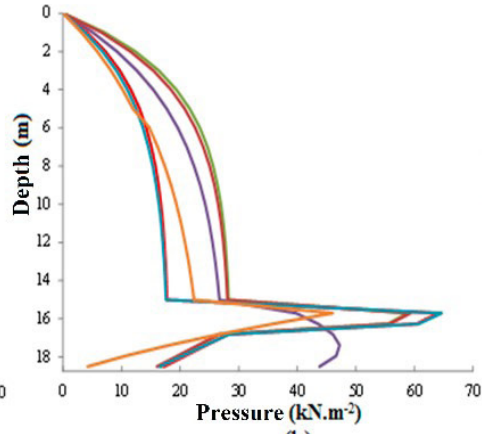

(b)

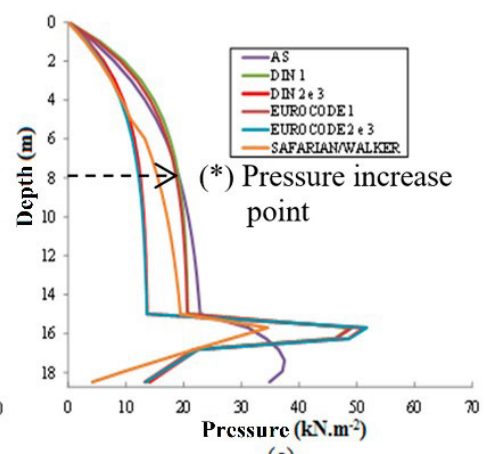

(c)

Figure 14: Dynamic horizontal pressure (or discharge) in the concentric hopper silo for: (a) corn, (b) crushed corn and (c) soybean meal.
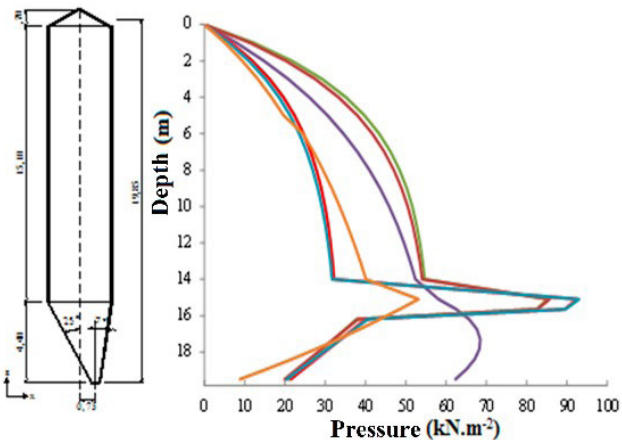

(a)

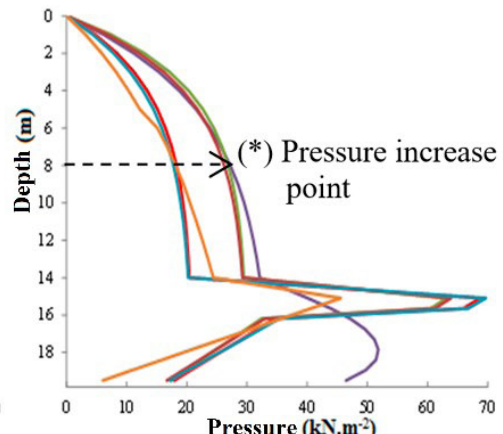

(b)

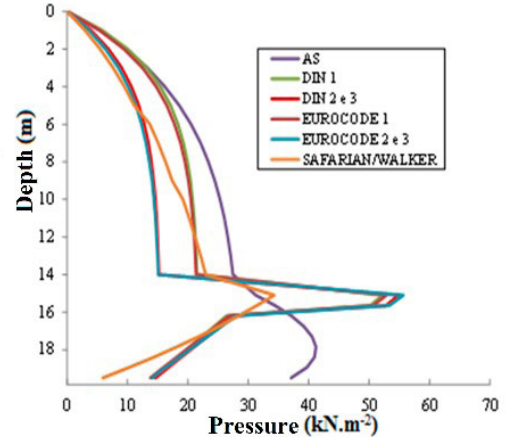

(c)

Figure 15: Dynamic horizontal pressure (or discharge) at the eccentric hopper silo $\left(e_{o} / a=25 \%\right)$ for: (a) corn, (b) crushed corn and (c) soybean meal.

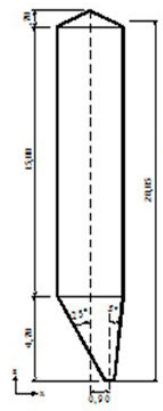

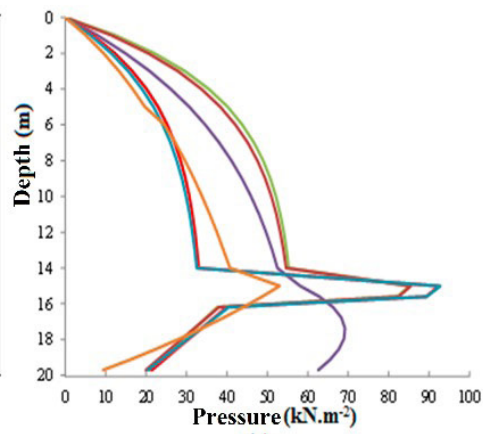

(a)

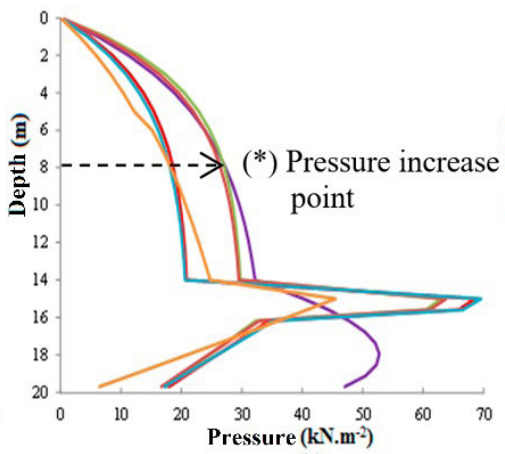

(b)

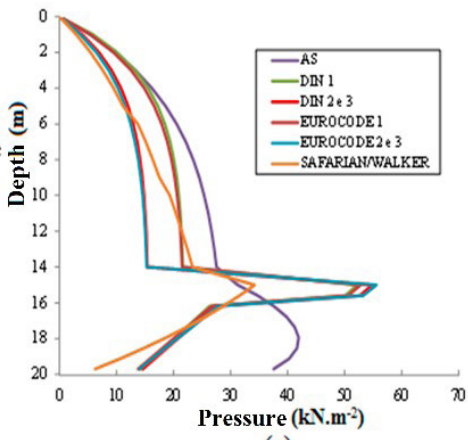

(c)

Figure 16: Dynamic horizontal pressure (or discharge) in the eccentric hopper silo $\left(\mathrm{e}_{\mathrm{o}} / \mathrm{a}=30 \%\right)$ for: (a) corn, (b) crushed corn and (c) soybean meal.
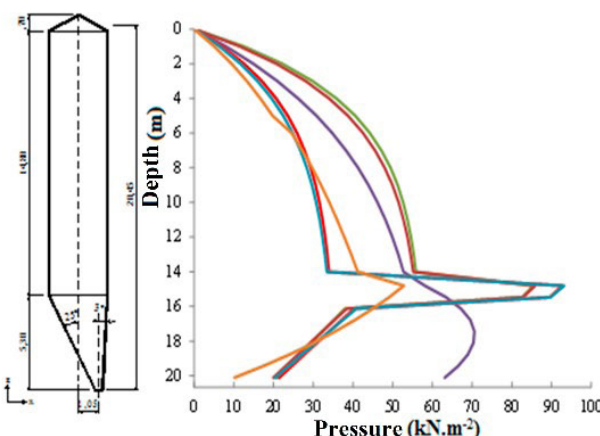

(a)

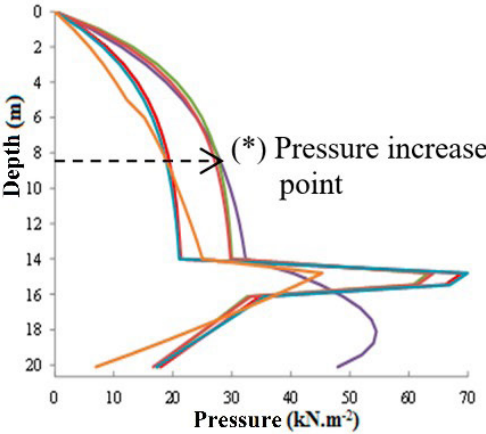

(b)

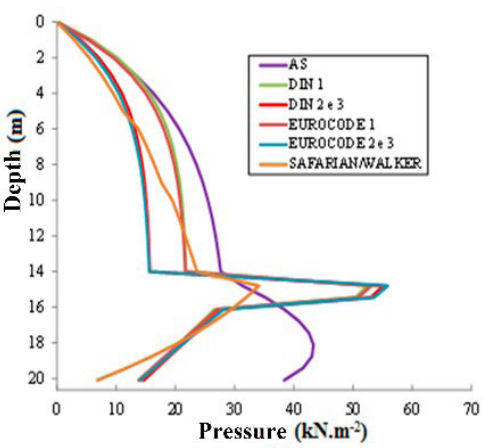

(c)

Figure 17: Dynamic horizontal pressure (or discharge) in the eccentric hopper silo $\left(\mathrm{e}_{\mathrm{o}} / \mathrm{a}=35 \%\right)$ for: (a) corn, (b) crushed corn and (c) soybean meal. 
For the dynamic friction pressures calculated on the walls near the transition of the eccentric outlet silo, mean values are equal to $8.40 \mathrm{kN} . \mathrm{m}^{-1}$ for corn, $8.46 \mathrm{kN} . \mathrm{m}^{-1}$ for crushed corn, and 7.50 $\mathrm{kN} . \mathrm{m}^{-1}$ for soybean meal. These values were on average $9 \%$ higher than the values observed in concentric output silos with average values of $7.70 \mathrm{kN} . \mathrm{m}^{-1}$ for corn, $7.74 \mathrm{kN} . \mathrm{m}^{-1}$ for crushed corn and $6.79 \mathrm{kN} . \mathrm{m}^{-1}$ for soybean meal, by standards, and Safarian theory.

With the dynamic friction pressures calculated at the bottom of the silo body of the eccentric hoppers, average values are observed at 17.70 $\mathrm{kN} . \mathrm{m}^{-1}$ for corn, $11.35 \mathrm{kN} . \mathrm{m}^{-1}$ for crushed corn and $10.53 \mathrm{kN} . \mathrm{m}^{-1}$ for soybean meal. These values were on average $8 \%$ higher than the concentric hopper with average values equal to $16.35 \mathrm{kN} . \mathrm{m}$ ${ }^{1}$ for corn, $10.46 \mathrm{kN} . \mathrm{m}^{-1}$ for crushed corn and 9.71 $\mathrm{kN} \cdot \mathrm{m}^{-1}$ for soybean meal, by the standards, and Walker's theory.
In determining the overpressure coefficient for Class 1 silos (EUROCODE and DIN), the hopper eccentricity is considered in the calculation. Observed in the body of the silo the mean friction pressures of the Safarian theory, present values above a certain depth, in relation to the norms, having the highest value of overpressure coefficients, which was 1.93.

Madrona and Calil Júnior (2009), researching $25 \%$ eccentricity conical hopper cylindrical silos, found that the side near the outlet has lower hopper friction pressures than the opposite side. The friction pressures calculated by the standards are higher than those obtained in numerical simulation using the finite element process. This type of behavior was also observed by Guaita, Couto and Ayuga (2003).

Figures 19 to 23 show the dynamicfriction pressure curves according to Safarian (1969) and Walker (1966) theories, for the three products analyzed.
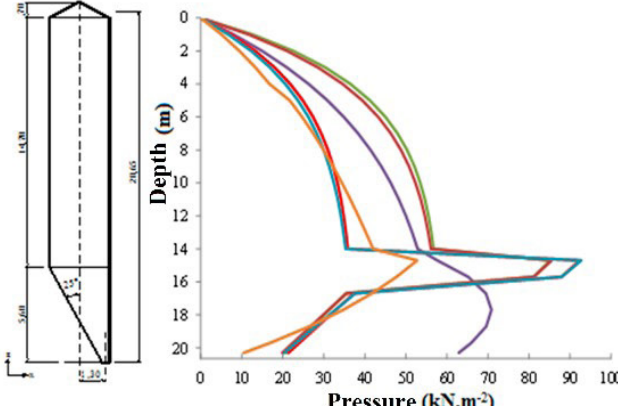

(a)

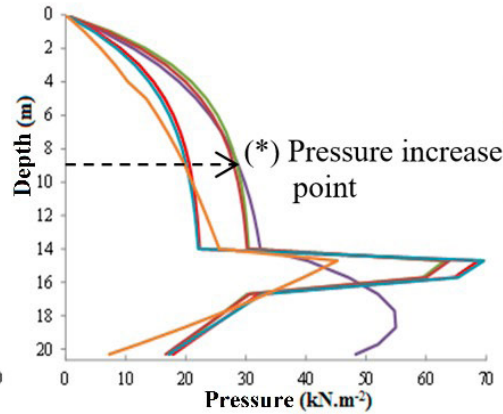

(b)

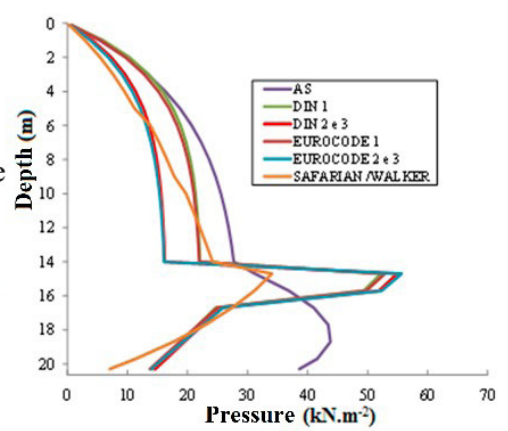

(c)

Figure 18: Dynamic horizontal pressure (or discharge) in the eccentric hopper silo $\left(e_{o} / a=43 \%\right)$ for: (a) corn, (b) crushed corn and (c) soybean meal.

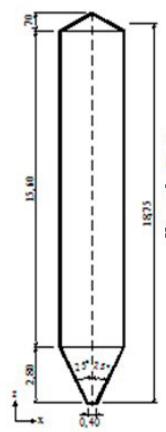

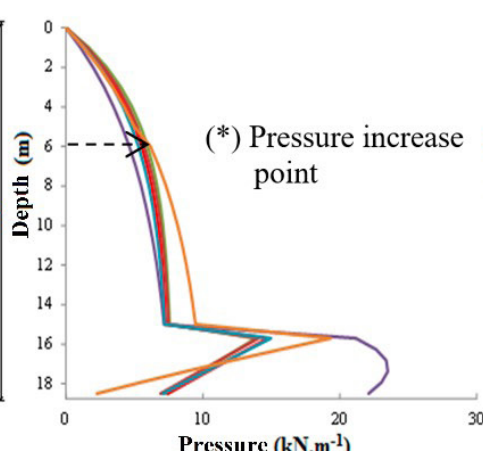

(a)

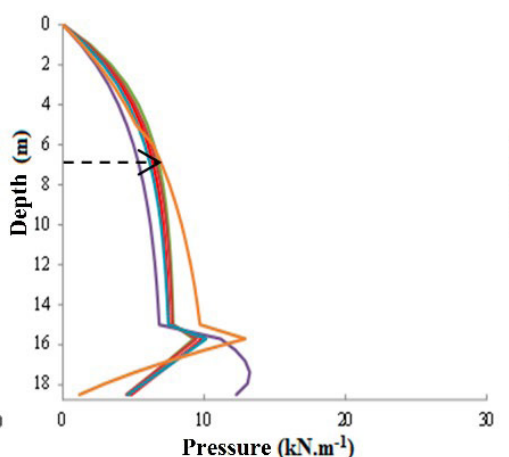

(b)

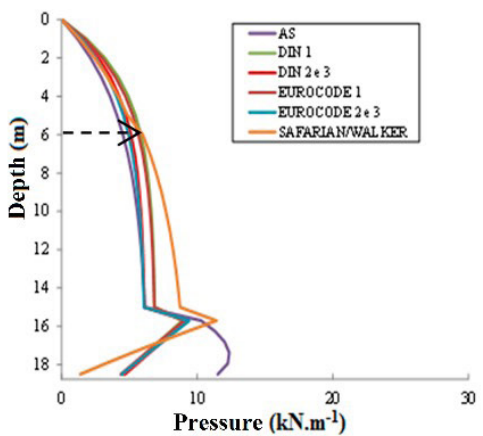

(c)

Figure 19: Dynamic (or unloading) friction pressure in the concentric hopper silo for: (a) corn, (b) crushed corn and (c) soybean meal. 

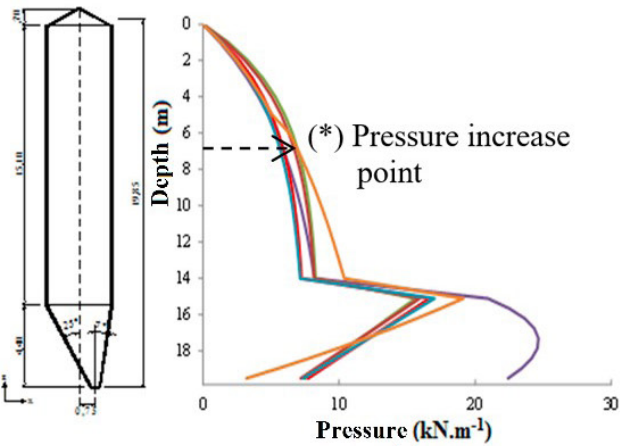

(a)

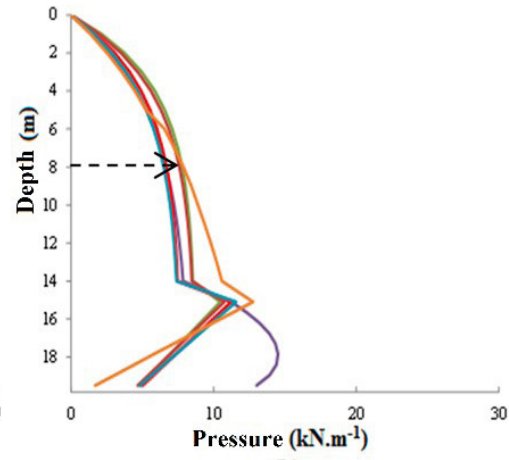

(b)

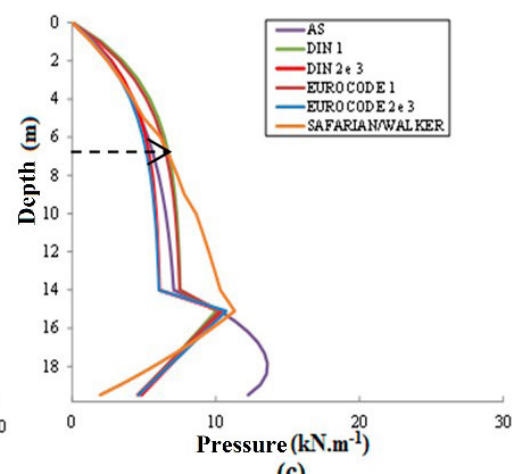

(c)

Figure 20: Dynamic friction (or discharge) pressure in the eccentric hopper silo $\left(\mathrm{e}_{\mathrm{o}} / \mathrm{a}=25 \%\right)$ for: (a) corn, (b) crushed corn and (c) soybean meal.

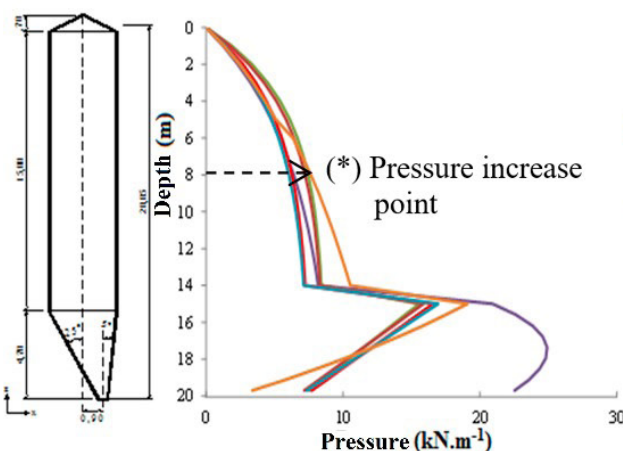

(a)

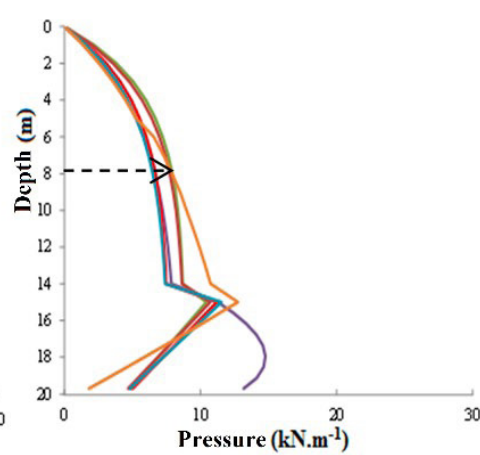

(b)

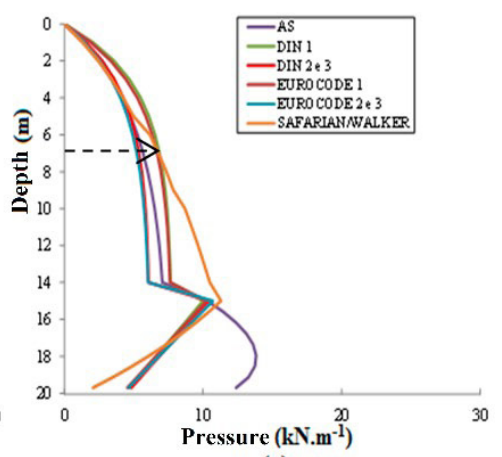

(c)

Figure 21: Dynamic friction (or discharge) pressure in the eccentric hopper silo $\left(\mathrm{e}_{\mathrm{o}} / \mathrm{a}=30 \%\right.$ ) for: (a) corn, (b) crushed corn and (c) soybean meal.

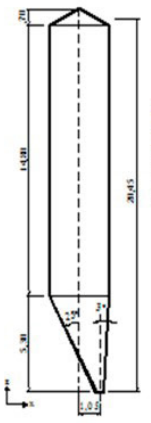

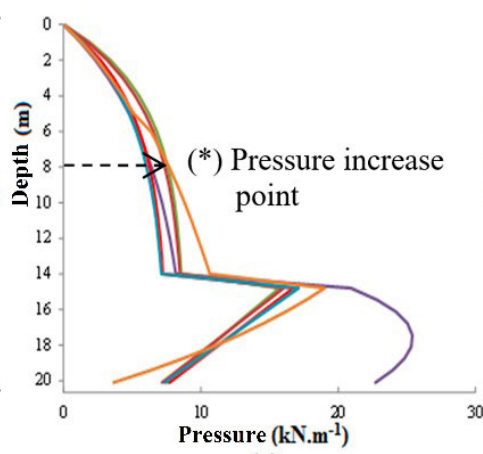

(a)

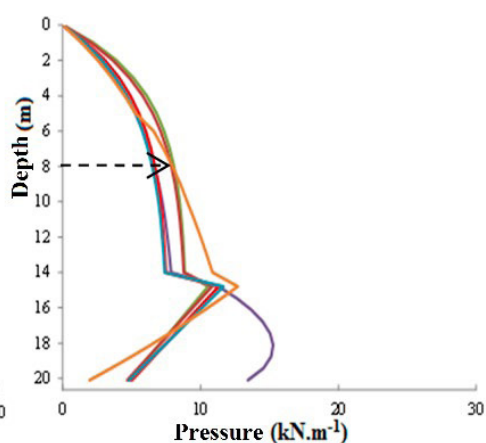

(b)

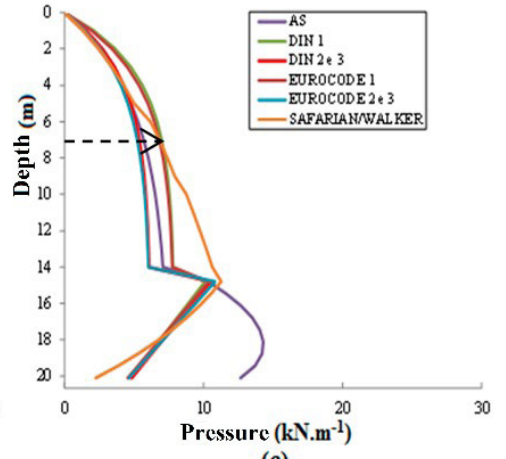

(c)

Figure 22: Dynamic friction (or discharge) pressure in the eccentric hopper silo $\left(\mathrm{e}_{\mathrm{o}} / \mathrm{a}=35 \%\right)$ for: (a) corn, (b) crushed corn and (c) soybean meal.
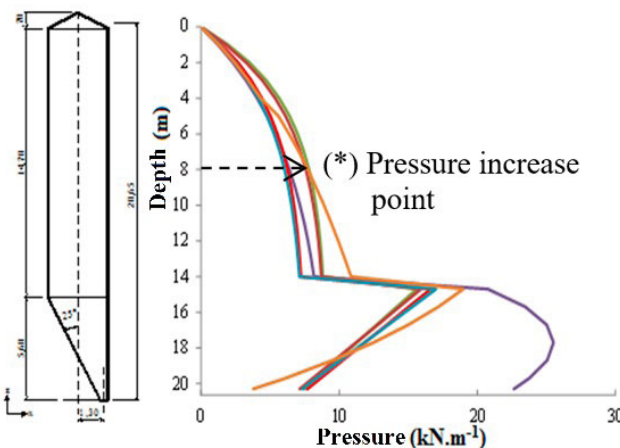
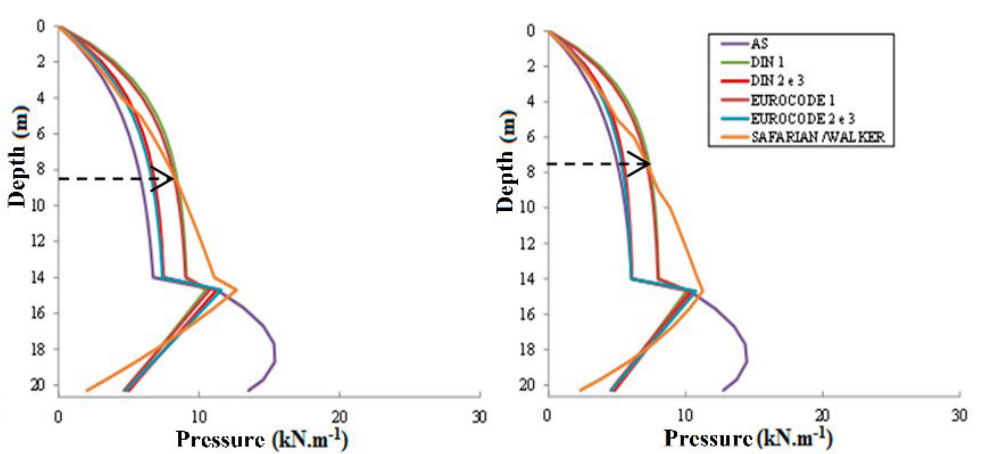

Figure 23: Dynamic friction (or discharge) pressure in the eccentric hopper silo $\left(e_{o} / a^{(c)}=43 \%\right.$ ) for: (a) corn, (b) crushed corn and (c) soybean meal. 


\section{CONCLUSIONS}

The SILOEXCENTRIC computational program made it easy and fast to be applicable for prismatic slender silos with concentric and eccentric hopper geometry. The results of vertical, horizontal, and frictional pressures were found to be in line with international standards, considered the LimitStates, providing a calculation report and pressure graphs.

\section{REFERENCES}

AMERICAN CONCRETE INSTITUTE. ACI 313: standard practice for the design and construction of concrete silos and stacking tubes for storing granular materials. Detroit, 1977. 38 p.

AUSTRALIAN STANDARD. AS 3774: loads on bulk containers. Sydney, 1996. 78 p.

BRITISH STANDARD EUROCODE. BS EN 19914: actions on silos and tanks: part 4: silos and tanks. Brussels, 2006. 107 p.

BROWN, C. J.; NIELSEN, J. Silos: fundamentals of theory, behaviour and design. London: E \& FN Spon, 1998. $836 \mathrm{p}$.

CALIL JÚNIOR, C.; NASCIMENTO, J. W. B.; ARAÚJO, E. C. Silos metálicos multicelulares. São Carlos: USP, 1997. 175 p.

CHEUNG, A. B. Modelo estocástico de pressões de produtos armazenados para a estimativa da confiabilidade estrutural de silos esbeltos. 2007. 305 p. Tese (Doutorado em Engenharia de Estruturas) Universidade de São Paulo, São Carlos, 2007.

DEUTSCHE NORM. DIN 1055-6: basis of design and actions on structures, part 6: design loads for buildings and loads in silos bins. Berlin: Verlaz, 2005. 112 p.

GAYLORD JUNIOR, E. H.; GAYLORG, C. N. Design of steel bins for storage of bulk solids. New Jersey: Prentice-Hall, 1984. 359 p.

GUAITA, M.; COUTO, A.; AYUGA, F. Numerical simulation of wall pressure during discharge of granular material from cylindrical silos with eccentric Hoppers. Biosystems Engineering, London, 85 (1):101-109, 2003.
LOPES NETO, J. P.; NASCIMENTO, J. W. B. Características de fluxo e projeto de tremonhas cônicas em silos verticais. Revista Brasileira de Engenharia Agrícola e Ambiental, Campina Grande, 17(3):339-345, 2013.

LOPES NETO, J. P.; NASCIMENTO, J. W. B.; CALIL JUNIOR, C. Análise de silos metálicos prismáticos. Ciência \& Agrotecnologia, Lavras, 32(4):1252-1258, 2008.

LOPES NETO, J. P.; NASCIMENTO, J. W. B.; FANK, M. Z. Forças verticais e de atrito em silos cilíndricos com fundo plano. Revista Brasileira de Engenharia Agrícola e Ambiental, Campina Grande, 18(6):652657, 2014.

MADRONA, F. S.; CALIL JÚNIOR, C. Análise das pressões em silos esbeltos com descarga excêntrica. Cadernos de Engenharia de Estruturas, São Carlos, 11(49):37-56, 2009.

MCLEAN, A. G. Empirical 4 critical flow factor equations. Bulk Solids Handling, Nuremberg, 6 (4):407-411, 1986.

MOLENDA, M.; HORABIK J.; THOMPSON S. A.; ROSS I. J. Bin loads induced by eccentric filling and discharge of grain. Structures \& Environment Division of ASAE, Saint Joseph, 45(3):781-785, 2001.

PALMA, G.; CALIL JÚNIOR, C. Pressões e fluxo em silos esbeltos $(h / d \geq 1.5)$. Cadernos de Engenharia de Estruturas, São Carlos, 10(42):129-150, 2008.

RAVENET, J. Silos. Barcelona: Técnicos Associados, 1992. $508 \mathrm{p}$.

SAFARIAN, S. S. Design pressures of granular materials in silos. Journal of the American Concrete Institute, New York, 66(8):647-655, 1969.

WALKER, D. M. An approximate theory for pressures and arching in hoppers. Chemical Engineering Science, New York, 21:975-997, 1966. 